Jurnal Interpretasi Hukum |ISSN: 2746-5047

Vol. 2, No. 2 - Agustus 2021, Hal.366-371| Tersedia online di

https://www.ejournal.warmadewa.ac.id/index.php/juinhum

DOI : https://doi.org/10.22225/juinhum.2.2.3442.366-371

\title{
PERLINDUNGAN HUKUM BAGI PEMEGANG KARTU E-MONEYSEBAGAI ALAT PEMBAYARAN DALAM TRANSAKSI NON TUNAI
}

\author{
I Kadek Ary Astrawan, I Nyoman Putu Budiartha \& Ni Made Puspasutari Ujianti \\ Fakultas Hukum Universitas Warmadewa, Denpasar-Bali, Indonesia \\ aryastrawan98@gmail.com, budiarthaputu59@gmail.com, puspaniwapong@gmail.com
}

\begin{abstract}
Abstrak
Perkembangan teknologi membawa perubahan pada sistem transaksi tunai dengan transaksi pembayaran digital. Salah satu alat pembayaran digital yang dimaksud adalah uang elektronik atau yang dikenal dengan E-Money. Meskipun pada awalnya banyak keraguan akan keamanan sistem pembayaran ini, Bank Indonesia menjawabnya dalam peraturan Nomor 20/6/PBI/2018 dengan mengatur prinsip-prinsip perlindungan konsumen termasuk di dalamnya penggantian kerugian terhadap masalah finansial meskipun mekanismenya belum begitu efektif. Ketidakefektifan yang dimaksud adalah adanya potensi penafsiran yang berbeda dalam peraturan tersebut. Ada dua fokus dalam kajian ini yaitu tentang invesitagis mekanisme pengaturan hukum terhadap pemilik kartu dana (E-money) dalam melakukan transaksi digital dan mekanisme perlindungan hukumnya apabila terjadi kerugian finansial karena kehilangan kartu dana (E-Money). Terkait masalah tersebut, penelitian ini dilakukan dengan menerapkan metode penelitian hukum normatif untuk mengkaji kebijakan tersebut, dengan menggunakan pendekatan perundang-undangan. Setelah proses analisis, hasil yang ditemukan adalah penggantian kerugian yang tercantum dalam peraturan di atas hanya bisa dijalankan jika kerugian merupakan kegagalan sistem $E$ Money pihak penerbit. Tentunya, hal ini mengabaikan prinsip perlindungan konsumen karena sebagai penerbit, Bank tidak bertanggung jawab atas kerugian pemilik E-Money.
\end{abstract}

Kata Kunci: E-money (uang elektronik), perlindungan hukum, transaksi non-tunai.

\begin{abstract}
Technological developments have brought changes to payments in the form of cash in the form of conventional metal and paper, which have now developed in the form of electronic payment instruments. One means of payment with an electronic or non-cash system is by using an E-Money card. Through Bank Indonesia Regulation Number 20/6 / PBI / 2018, regulations have been stated regarding the application of consumer protection principles which also regulate the financial loss compensation mechanism but have not clearly and in detail how the compensation mechanism is. In this case there is a blur of norms by the ambiguity of this regulation which causes different interpretations between one institution and another. There are two focuses on this research, about investigation of the legal regulatory mechanism against fund card (E-money) owners in conducting digital transactions and the legal protection mechanism in the event of financial loss due to loss of fund card (E-Money). The research method used in this paper is the normative legal research method, namely researching legal principles and examining written regulations. In conclusion, compensation for E-Money can only be done if it is the damage of the issuer. Banks as electronic money issuers are not responsible for the losses of EMoney owners where this rule violates consumer protection principles.
\end{abstract}

Keywords: Legal Protection, Electronic Money (e-money) Non-Cash Transactions

\section{PENDAHULUAN}

Hari ini, perkembangan teknologi berperan besar terhadap pergeseran pola kehidupan masyarakat, tidak terkecuali cara masyarakat berinteraksi antar sesama. Salah satu bukti perubahan nyata yang acap kali kita temui, atau mungkin kita bagian darinya adalah pergeseran penggunaan alat pembayaran yang tadinya berupa uang fisik (logam/kertas) menjadi uang digital atau elektronik yang dikenal dengan E-money (Sunaryo, 2009) 
Dalam praktiknya E-Money (uang elektronik) menggunakan alat yang dinamakan Stored Value Card (kartu penyimpan dana) atau lebih dikenal dengan kartu prabayar. Perihal penggunaan jenis alat pembayaran ini diatur terpisah dari jenis alat pembayaran lainnya seperti Debit Card (kartu debit), Credit Card (kartu kredit), dan Automated Teller Machines Card (kartu ATM). Transaksi pembayaran dengan E-money biasanya dilakukan dengan cara menempelkan kartu ke sensor yang telah disediaan oleh penjual sehingga dapat dilakukan pemotongan dana yang tersimpan pada kartu elektronik. Sistem pembayaran seperti ini sangatlah memudahkan konsumen untuk melakukan transakasi pembayaran dan konsumen yang bukan nasabah Bank penerbit E-money juga dapat mendapat manfaatnya karena alat ini dapat diterbitkan oelh lmbaga non-bank serta kepemilikannya tidak harus melalui proses otorisasi dari pihak bak sebagai penerbit E-money (Purnomo et al., 2012). Sistem seperti ini dapat mengurangi potensi tindak kejahatan karena konsumen tidak perlu membawa uang dalam jumlah yang banyak (Hermansyah, 2012). Apabila dana tersimpan habis, maka, pengisian ulang dapat dilakukan. Pada dasarnya sifat E-Money merupakan alat prabayar yang sepenuhya merupakan kuasa konsumen dan bukan simpanan nasabah yang dilindungi sepenuhnya oleh bank, maka, kehilangan dan bentuk kerugian terhadap konsumen umumnya merupakan tanggungjawab mereka sepenuhnya.

Terkait persoalan transaksi pembayaran digital, Bank Indonesia sebagai lembaga pengatur keuangan berkewajiban menjamin sistem tersebut dapat dijalankan dengan efektif, efisien, dan aman. Perlu diingat bahwa rasa aman dan nyaman pada pengguna merupakan hal utama yang harus dilindungi disamping perlindungan terhadap pelaku usaha. Tidak adanya proses otorisasi menjadikan kemanan transaksi melalui E-money menjadi rentan terhadap kebocoran ataupun penyalahgunaan alat oleh pihak ketiga yang, tentu saja, berpotensi menimbulkan kerugian bagi pengguna E-money. Perlindungan hak terhadap keamanan dan kenyamanan penggunaan E-Money oleh pemilik mestinya menjadi perhatian utama agar mencapai sasaran yang diinginkan oleh lembaga perbankan dalam meningkatkan efisiensi dalam bertransaksi menggunakan layanan perbankan. Sehingga perlindungan hukum diperlukan oleh pemilik E-Money untuk menjamin kepastian hukum serta kesetaraan kedudukannya dengan penerbit $E$-Money, termasuk dalam kasus kehilangan, pencurian, atau penyalahgunaan kartu $E$ Money yang berujung pada kerugian.

Terkait masalah diatas, Bank Indonesia telah mengatur hukum perihal E-money yang mana telah mengalami tiga kali perubahan. Peraturan yang dimaksud adalah Peraturan Bank Indonesia Nomor 11/12/PBI/2009 tentang Uang Elektronik (Lembaran Negara Republik Indonesia Tahun 2016 Nomor 179, Tambahan Lembaga Negara Republik Indonesia Nomor 5925) yang kemudian digantikan oleh Peraturan Bank Indonesia Nomor 18/17/PBI/2016, namun, kedua peraturan tersebut belum mengatur perihal prinsip perlindungan konsumen khususnya pada mekanisme penggantian kerugian finansial kepada pengguna. Barulah pada perubahan terakhir (Peraturan Bank Indonesia Nomor 20/6/PBI/2018) hal-hal berkenaan penerapan prinsip perlindungan konsumen diatur, dimana diantaranya ialah mengenai mekanisme penggantian kerugian finansial kepada pengguna yang dapat dilihat pada Pasal 43 ayat (2) huruf c. Kendatipun, peraturan yang dimaksud belumnya menyentuh area yang terperinci, contohnya ketika pengguna kehilangan kartu E-Money bukan karena kelalaian atau kesalahannya sendiri melainkan adanya keadaan tidak terduga seperti pencurian atau perampokan (Miru, 2015).

Beberapa penelitian terdahaulu yang relevan dengan penelitian ini, yang membahas mengenai perlindungan hukum bagi nasabah pemegang E-money yang diterbitkan oleh bank (Haryana, 2016). Dalam penelitiannya ditemukan bahwa ada beberapa upaya hukum bagi pemegang E-money yakni upaya hukum preventif dan upaya hukum represif. Hukum adalah kumpulan peraturan atau kaidah yang dipaksakan penerapannya dalam kehidupan manusia yang mengakibatkan adanya sanksi bila melanggar hukum tersebut (Sudikno, 1996). Menurut, Sitorus (2018) adanya perlindungan hukum yang kosong terhadap pemegang kartu uang elektronik 
ketika hilang, hal ini disebabkan karena kartu e-money tidak terigistrasi makan hal tersebut bukan tanggungjawab ari pihak bank. Sedangkan, dalam penelitian Dayi (2018) memaparkan bahwa adanya perlindungan hukum bagi pemegang uang elektronik ditinjau dari POJK Nomor 1/POJK.07/2013 Tentang Perlindungan Konsumen Sektor Jasa Keuangan. Dari penjelasan beberapa penelitian terdahulu, kemudian peneliti menyimpulkan bahwa tidak adanya peraturan yang jelas dan tegas perihal peraturan berakibat pada penafsiran beragam pada berbagai lembaga (bank dan non-bank). Perlindungan terhadap konsumen sebagai pemegang kartu dana uang elektronik menjadi hal penting yang harus diperhatikan dengan begitu kompleksnya permasalahan yang menyangkut perlindungan hukum ini serta dalam rangka menyambut perdagangan bebas kedepannya. Sebagaimana telah disampaikan dalam diskusi sebelumnya maka terdapat dua fokus dalam kajian ini yaitu tentang invesitagis mekanisme pengaturan hukum terhadap pemilik kartu dana (E-money) dalam melakukan transaksi digital dan mekanisme perlindungan hukumnya apabila terjadi kerugian finansial karena kehilangan kartu dana (E-Money).

\section{METODE PENELITIAN}

Metode yang dipakai merupakan kajian hukum normatif yang beracuan pada peraturan dalam undang-undang yang dianalisa dengan sistematis (Efendi \& Ibrahim, 2016), serta mempelajari terori-teori serta asas-asas hukum dan peraturan perundang-undangan terkait. Teknik pengumpulan data menggunakan pendekatan dokumentasi dimana data dikumpulkan dengan melibatkan bahan yang terdapat pada dokumen hukum atau literatur terkait. Sedangkan analisa masalah dilakukan dengan melakukan pendekatan perundang-undangan dimana kajian ini memanfaatkan pengkajian terhadap regulasi serta undang-undang terkait isu hukum yang menjadi perhatian.

\section{HASIL DAN PEMBAHASAN}

\section{Pengaturan Hukum Terhadap Pemegang Kartu E-Money Dalam Melakukan Transaksi Non Tunai}

Berdasarkan Undang-Undang No. 3/2004 tentang Bank Indonesia, institusi ini memiliki kuasa untuk menentukan alat pembayaran yang berlaku dalam rangka penjagaan serta pengaturan terhadap efisiensi, efektifitas, dan keamanan sistem pembayaran yang ada di Indonesia. Terkait hal ini, kemunculan dan kemajuan teknologi berdampak pada lahirnya perubahan-perubahan dalam sistem pembayaran, salah satunya adalah dengan berkembangnya sistem pembayaran elektronik (Electronic Payment). Bertindak sebagai bank pusat yang ada di Indonesia, Bank Indonesia memiliki andil terhadap keputusan dan penentuan kebijakan moneter untuk mengatur sistem pembayaran, termasuk didalamnya tentang penggunaan E-Money. Perihal ini telah diatur dalam PBI No. 16/08/PBI/2014. E-Money diputuskan sebagai salah satu alat pembayaran demi tujuan kemudahan dan bukan untuk menggantikan fungsi uang secara keseluruhan sebagai alat pembayaran yang sah. Oleh karenanya pemegang kartu E-money hendaklah menggunakan alat ini sesuai dengan kadar kebutuhan.

Dalam PBI No.16/1/PBI/2014, Bank Indonesia telah mengatur perihal perlindungan terhadap pengguna jasa sistem pembayaran dimana didalamnya mencakup perlindungan terhadap pengguna E-money. Hal tersebut tentang perlindungan hak konsumen pengguna jasa sistem pembayaran memiliki keterkaitan dengan Undang-Undang No. 8/1999 dalam masalah yang sama. Dalam rincian-rincian terkait, Bank Indonesia juga mngeluarkan beberapa peraturan menyangkut penyelenggaraan sistem pembayaran elektronik dengan kartu (Debit card, ATM Card, E-money) seperti:

1. PBI No. 6/30/PBI/2004, No. 7/52/PBI/2005, dan No. 11/11/PBI/2009 tentang Penyelenggaraan Kegiatan Alat Pembayaran Menggunakan Kartu

2. PBI Nomor $14 / 2 / \mathrm{PBI} / 2012$ tentang Perubahan atas PBI Nomor $11 / 11 / \mathrm{PBI} / 2009$

3. PBI No. 10/8/PBI/2008 tentang Perubahan PBI No. 7/52/PBI/2005 
4. PBI Nomor 11/12/PBI/2009 tentang Uang Elektronik (Electronic Money), dan

5. PBI Nomor 10/4/PBI/2008 tentang Laporan Penyelenggaraan Kegiatan Alat Pembayaran Menggunakan Kartu oleh BPR (Bank Perkreditan Rakyat) serta lembaga non-Bank

Terkhusus kepada peraturan terhadap kegiatan transaksi dengan E-Money diatur dalam PBI No. 11/12/PBI/2009 tentang Uang Elektronik oleh Bank Indonesia dengan kewenangannya selaku bank pusat di Indonesia. Peraturan terkait terdapat pula dalam Surat Edaran No. 11/11/DASP/2009 tentang Uang Elektronik. Kedua regulasi tersebut mengatur tentang perihal mekanisme (tata cara dan syarat) dan hal-hal lain dalam pelaksanaan penyelenggaraan pembayaran dengan E-money demi kenyamanan, keamanan dan kelancaran kegiatan dengan sistem digital (E-money).

\section{Perlindungan Hukum Bagi Pemegang Kartu E-Money Apabila Terjadi Kerugian Akibat Hilangnya Kartu E-Money}

Mengenai uang elektronik yang hilang maupun dicuri, segala akibat kehilangan ataupun dicuri merupakan tanggung jawab penuh pemilik uang elektronik dan pemilik uang elektronik tidak dapat melakukan pemblokiran. Tidak seperti tabungan dalam rekening nasabah, jika hilang atau dicuri kartu dana (E-money) tidak dapat dicari keberadaannya karena tidak adanya proses otorisasi yang melibatkan kode verifikasi serta tidak memungkinakan dilakukan pelacakan terhadap penggunaannya karena sifatnya di luar jaringan (offline). Oleh karenanya, pemakaian E-money sebagai alat bayar elektronik berpotensi terdhadap timbulnya masalah yang kadang merugikan konsumen selaku pengguna uang elektronik. Ketidaksadaran dan ketidaktahuan konsumen akan faedah dan manfaat jasa dan/atau barang yang dipakai acap kali berujung pada kerugian yang selama ini diderita konsumen (Tumantra, 2016)

Pada dasarnya, perlindungan hukum dapat dilakukan oleh penerbit uang elektronik dengan menerapkan sistem perlindungan dengan memaksimalkan akses konsumen terhadap informasi terkait barang dan jasa yang digunakan, memperketat keamanan penyelenggaraan kegiatan terkait jasa/barang, dan memamksimalkan pelayanan terhadap kepastian hokum kepada konsumen mengingat tujuan dasar dari hukum ialah menyediakan jaminan keamanan termasuk dalam hal ini dalam pelayanan kegiatan pembayaran terhadap konsumen dengan E-money.

Bank sebagai sebuah badan keuangan memiliki izin untuk melakukan pengumpulan dana dalam bentuk tabungan dan penyaluran dana tersebut kepada masyarakat yang membutuhkannya. Keberlangsungan dan keberadaan Bank sebagai sebuah badan keuangan sangatlah bergantung kepada harapan dan keyakinan nasabah terhadap produk jasa yang ditawarkan. Hal ini menjadi sangat fundamental dan krusial bagi Bank karena masyarakat pada dasarnya memiliki kebebasan untuk memilih badan penyedia jasa keuangan lainnya (non-bank) yang dipercaya atau bahkan menginvestasikan kelebihan dana yang mereka miliki dalam bentuk aset (fisik dan non-fisik).

Hubungan antara nasabah (konsumen) dan bank sebagaimana disebutkan diatas merupakan hubungan non-kontraktual. Namun, dalam pelaksanaan kegiatan perbankan hubungan lain yang kontraktual juga menjadi hal mendasar lainnya dan fundamental dalam menjaga hubungan baik dengan nasabah. Pada pelaksanaannya, hubungan jenis ini diwujudkan dalam bentuk perjanjian tertulis yang baku antara bank dengan nasabah. Dalam hal ini, isi perjanjian umumnya dibuat oleh pihak yang memiliki posisi tawar lebih tinggi seperti bank untuk pihak lainnya (nasabah) dan kemudian disetujui kedua belah pihak dengan bukti tanda tangan masing-masing pihak sebagai bentuk kesaksian dan kesanggupan serta kesediaan tanggung jawab atas kesepakatan pihak-pihak yang terkait dalam perjanjian.

Meskipun begitu, dalam kasus penyelenggaraan kegiatan pembayaran dengan kartu dana pembayaran (E-money), konsumen (nasabah dan non-nasabah) tidak memiliki perlindungan hukum untuk melakukan tuntutan dan meminta pertanggungjawaban kepada pihak terkait Bank (pegawai, mitra, dan pejabat) akan perihal seperti kerusakan serta kehilangan kartu 
karena kelalaian dan kesalahan pemilik, kerugian finansial akibat kesalahan dalam prosedur transaksi, dan penyalahgunaan kartu akibat pencurian data oleh pihak tidak berwenang.

Pada dasarnya perlindungan terhadap keamanan pengguna terkait hal-hal tersebut dapat dilakukan dengan mengatur ketentuan kaidah-kaidah perjanjian baku dan segala hal ikhwal terkait prinsip dasar, sifat, penentuan kewajiban dan hak yang diatur memalui peraturan perundang-undangan (perlindungan preventif). Selain itu, apabila terjadi kasus sengketa dalam kegiatan penyelengaraan pembayaran melalui uang elektronik, pihak Bank dapat menempuh jalan penyelesaian dengan pendekatan non-litigasi (musyawarah) dan litigasi (melalui proses peradilan) dimana hal ini merupakan perwujudan perlindungan represif terhadap hak konsumen. Sebagaimana dijelaskan sebelumnya bahwa peraturan penyelengaraan kegiatan pembayaran dengan kartu dana (E-money) yang diatur oleh Bank Indonesia belum menyentuh area yang terperinci sehingga masih ada kasus dimana kerugian yang dirasakan oleh pemegang kartu tidak dapat dipertanggungjawabkan, maka, dalam perjanjian dan peraturan baku perlu ditegaskan mengenai batasan-batasan kewajiban dan hak pengguna guna terciptanya perlindungan hukum yang maksimal terhadap konsumen. Perincian hal terkait hak konsumen yang dimaksud, yang dapat dituangkan dalam perjanjian dan peraturan baku yang dikeluarkan contohnya memasukkan penjaminan keamanan yang meliputi otentifikasi kartu bagi pemilik dengan menerapkan enkripsi data pengguna agar terlindungi dari pihak-pihak tidak berwenang, Bank juga dapat menentukan ambang batas jumlah penyimpanan dana oleh konsumen dalam usaha mengurangi potensi kerugian apabila terjadi penyalahgunaan kartus serta melakukan sosialisasi dan edukasi kepada konsumen mengenai hal ikhwal terkait penggunaan kartu dana (E-money) sebagai alat pembayaran. Kemudian, badan atau lembaga yang tidak melakukan atau memasukkan hal-hal diatas dapat dituntut atau dimintai pertanggungjawabannya sebagaimana aturan yang berlaku terkait penggunaan uang elektronik setelah dilakukan perbaikan.

\section{KESIMPULAN DAN SARAN}

\section{Kesimpulan}

Berdasarkan hasil analisis diatas peneliti kemudian menarik kesimpulan bahwa Pengaturan hukum bagi pemilik uang elektronik sebagai alat pembayaran non tunai apabila terjadi kerugian akibat hilangnya kartu E-Money sebagaimana diatur dalam Peraturan Bank Indonesia Nomor 20/6/PBI/2018 belum diatur secara maksimal meskipun dalam penggunaannya uang elektronik memberikan banyak manfaat dan dapat mempermudah dalam transaksi namun apabila uang elektronik hilang atau dicuri tidak akan mendapat penggantian kerugian maupun pemblokiran. Pemberian pergantian uang elektronik hanya dapat dilakukan apabila hal tersebut merupakan kerusakan dari penerbit. Kemudain Bank sebagai penerbit uang elektronik tidak bertanggung jawab atas kerugian yang diderita oleh pengguna uang elektronik apabila uang elektronik hilang ataupun dicuri, segala akibat kehilangan ataupun dicuri merupakan tanggung jawab penuh pemilik atau pemegang uang elektronik dan pemilik uang elektronik tidak dapat melakukan pemblokiran yang mana dapat dikatakan bahwa peraturan ini melanggar prinsip perlindungan konsumen.

\section{Saran}

Melalui kajian ini, peneliti ingin menyampaikan beberapa saran kepada pihak-pihak terkait yang diharapkan dapat membantu memperbaiki regulasi keuangan di Indonesia. Pertama, diharapkan kepada Otoritas Jasa Keuangan dan Bank Indonesia sebagai pihak yang berwenang hendaklah mengatur kegiatan terkait pembayaran dengan uang elektronik harus menambahkan detail yang tegas dan jelas dalam peraturan yang dikeluarkan demi mencegah terjadinya penyalahgunaan dan kerugian finansial yang mungkin menimpa konsumen sebagi pemilik kartu dana. Dengan begitu keamanan, kenyamanan, effektifitas, dan efesiensi penggunaan uang elektronik sebagai alat pembayaran alternatif dapat terjamin. Kedua, kepada pihak penerbit uang elektronik (Bank dan Non-bank) untuk memberikan sosialisasi dan edukasi kepada calon konsumen akan hakikat 
E-money berdasarkan kaidah-kaidah yang berlaku untuk mencegah dan meminimalisir penyalahgunaan kartu dalam transaksi non-tunai oleh konsumen karena ketidaktahuan dan ketidaksadaran mereka akan hal ikhwal terkait E-money. Ketiga, Bagi konsumen yang memiliki kartu dana elektronik, merupakan hal yang penting untuk memahami dan mempelajari secara terperinci kekurangan yang ada pada sistem pembayaran dengan $E$-moneydemi mencegah terjadinya kesalahan dan kelalaian dalam penggunaan kartu dana elektronik pada transaksi pembayaran yang dapat mengakibatkan kerugian finansial bagi pemegang kartu. Keempat, Perlu adanya pengawasan dan supervisi oleh pihak otoritas penyedia jasa keuangan kepada setiap pihak yang terkait dalam pelaksananan kegiatan penggunaan uang elektronik dalam transaksi pembayaran non-tunai di Indonesia agar tercipta keamanan, kenyamanan, effektifitas, dan efesiensi dalam transaksi pembayaran dengan uang elektronik.

\section{DAFTAR PUSTAKA}

Dayi, H. (2018). Perlindungan Hukum Bagi Pemegang Uang Elektronik ditinjau dari POJK Nomor 1/POJK.07/2013 Tentang Perlindungan Konsumen Sektor Jasa Keuangan (Studi Tentang Klaim Ganti-Rugi Kartu Rusak). Fakultas Hukum, Universitas Islam Indonesia.

Efendi, J., \& Ibrahim, J. (2016). Metode Penelitian Hukum: Normatif dan Empiris. Kencana, Jakarta.

Haryana, F. S. (2016). Perlindungan Hukum Bagi Nasabah Pemegang Kartu E-Money Yang Diterbitkan Oleh Bank. Fakultas Ilmu Hukum, Universitas Airlangga.

Hermansyah. (2005). Hukum Perbankan Nasional Indonesia. Kencana Prenada Media Group, Jakarta.

Miru, A. (2011). Prinsip-prinsip Perlindungan Hukum Konsumen - Ahmadi Miru. PT Raja Grafindo Persada, Jakarta.

Purnomo, S. D., Serfiyani, C. Y., Hariyani, I., \& Simatur, Z. (2012). Untung dengan kartu kredit, kartu ATM-Debit, \& uang elektronik. Visimedia, Jakarta.

Sitorus, R. F. (2018). Perlindungan Hukum Pemegang Kartu Uang Elektronik Ketika Hilang. Novum: Jurnal Hukum, Vol.5(2).

Sudikno, M. (1996). Mengenal hukum suatu pengantar. Liberty, Yogyakarta.

Sunaryo, S. (2009). Hukum Informasi dan Elektronik. Rineka Cipta, Jakarta.

Turmantara, F. (2016). Hukum Perlindungan Konsumen. Setara Press, Malang. 